\title{
FENOMENA SOSIAL DALAM NOVEL SAUDAGAR BESAR DARI KUALA LUMPUR
}

\author{
MOHD FIRDAUS CHE YAACOB * \\ NASIRIN ABDILLAH ** \\ mohdfirdauscheyaakob@yahoo.com *
}

\begin{abstract}
Abstrak
Novel merupakan salah satu khazanah sastera Melayu yang paling popular sehingga kini. Oleh itu, novel juga penuh dengan fenomena sosial yang dapat memberi pendidikan kepada masyarakat. Kajian ini dilakukan untuk mengenal pasti dan menganalisis fenomena sosial dalam novel Saudagar Besar dari Kuala Lumpur oleh Keris Mas menerusi aspek ekonomi, politik, sosial, budaya serta aspek agama. Kajian ini menggunakan kaedah kepustakaan dan teks. Selain itu juga, Teori Sosiologi digunakan untuk diaplikasikan dalam memantapkan lagi kajian ini. Hasil kajian mendapati novel Saudagar Besar dari Kuala Lumpur oleh Keris Mas sememangnya kaya dengan perutusan fenomena sosial dalam novel tersebut.
\end{abstract}

Kata Kunci: Novel, fenomena sosial, Saudagar Besar dari Kuala Lumpur, Sosiologi.

* Pensyarah \& Pelajar PhD di Fakulti Teknologi dan Warisan, Universiti Malaysia Kelantan, Malaysia

** Pensyarah Kanan di Fakulti Teknologi Kreatif dan Warisan, Universiti Malaysia Kelantan, Malaysia 


\section{Abstract}

Novel is one of the most popular Malay literary until now. Therefore, the novel is also full of social phenomena that can educate the community. The study was conducted to identify and analyze social phenomena in the novel of Saudagar Besar dari Kuala Lumpur from Keris Mas through economic, political, social, cultural and religious aspects. This study uses literature and textual methods. In addition, Sociology Theory is used to improve the study. The study found that the Saudagar Besar dari Kuala Lumpur form Keris Mas was indeed rich in the message of social phenomena in the novel.

Keywords: Novels, social phenomena, Saudagar Besar dari Kuala Lumpur, Sociology.

* Lecturer \& Student PhD at Faculty of Creative Technology and Heritage, Universiti Malaysia Kelantan, Malaysia

** Senior Lecturer at Faculty of Creative Technology and Heritage, Universiti Malaysia Kelantan, Malaysia 

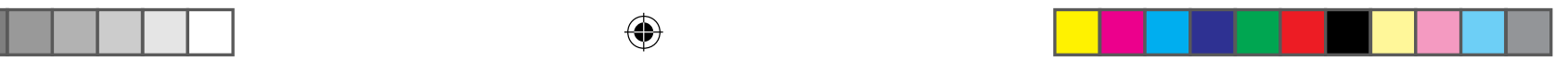

\subsection{Pengenalan}

Pada realitinya apabila berbicara tentang dunia sastera, ia merupakan suatu bidang yang bersifat seni halus yang disampaikan melalui pelbagai genre. Pelbagai definisi atau tafsiran mengenainya telah diutarakan oleh pengkaji kesusasteraan. Menurut pendapat Kamaruzzaman A. Kadir (1985:63) kesusasteraan adalah segala hasil ciptaan manusia melalui bahasa yang bersifat seni. Sebagai hasil seni, maka ciri utamanya mengandungi emosi, imaginasi dan budi. Manakala, menurut Danziger \& Johson (1983:2) berpendapat bahawa kesusasteraan secara luas merupakan seni yang menggunakan kata-kata tanpa memperhitungkan persoalan sama ada kata-kata itu tertulis atau diucapkan. Setiap novel yang dihasilkan oleh penulis itu mempunyai fungsi-fungsi khusus untuk menggambarkan tentang fenomena sosial yang melingkari dalam sesebuah kehidupan. Sehubungan itu, fenomena sosial juga merupakan salah satu medium yang sentiasa digarap oleh pengarang untuk menghasilkan sesebuah novel untuk menyampaikan unsur didaktik dalam setiap novel-novel ciptaan mereka. Fenomena sosial dalam sesebuah novel jelas mempunyai hubungan yang sementara serta tidak boleh dipisah-pisahkan. Oleh itu, setiap aspek pemilihan bahan-bahan atau gambaran cerita yang diceritakan dalam sesebuah novel yang dihasilkan itu telah diambil daripada setiap fenomena serta tindak-tanduk masyarakat diceritakannya. Pada pandangan seseorang pengarang, fenomena sosial dapat mengajak serta menarik sejumlah pembaca untuk dijadikan bahan-bahan penting sesuatu bidang yang meliputi aspek kajian, pendedahan serta panduan kepada warga pembaca. Oleh itu, kajian ini akan mengkaji fenomena sosial yang terkandung dalam novel Saudagar Besar Dari Kuala Lumpur oleh Keris Mas.

Menurut Hashim Awang (1998:4), fenomena sosial sebagai sesuatu yang boleh diperhatikan dan juga boleh dijadikan sebagai objek penelitian dan suatu penyelidikan yang kemudiannya boleh menghasilkan suatu penemuan yang berbentuk rumusan ataupun suatu gagasan yang tepat. Oleh itu, berdasarkan rumusan dan gagasan itulah dapat menyerlahkan lagi pola-pola sesuatu fenomena yang dapat dijadikan sasaran untuk penyelidikan dan penelitian. Seterusnya, Umar Junus (1989:80) menyatakan bahawa istilah sosial merujuk kepada hubungan karya dengan khalayaknya yang merupakan fenomena dalam proses penghasilan sesuatu karya daripada pergolakan sosial dalam masyarakat itu sendiri. Mohd Taib Osman (1989:80) menyatakan juga istilah sosial itu merujuk kepada kesemuanya yang mencerminkan atau yang dapat menggambarkan segala kehidupan manusia yang sudah pasti menyentuh soal sistem kekeluargaan, pendidikan, ekonomi, politik, kepercayaan dan agama dalam masyarakat. Selain itu, menurut Sidi Gazalba (1967:1-2) istilah sosial pula merujuk kepada masalah sosial yang menyentuh soal pergaulan, hubungan dan kehidupan kelompok manusia terutamanya dalam kehidupan bermasyarakat yang mempertahankan segala sistem peraturan dan hubungan antara seseorang dengan individu yang lain. Dalam konteks

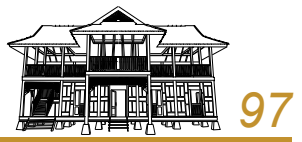



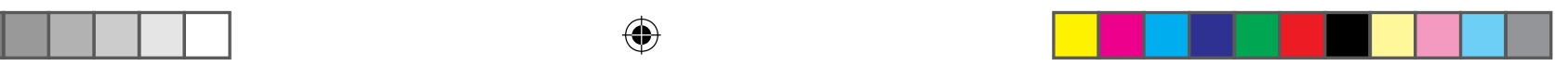

ini, maka jelas membuktikan tentang hubungan itu sudah pasti berlaku oleh sebab setiap individu itu saling memerlukan antara satu dengan yang lain, walaupun pada asasnya setiap kelompok sosial itu tidak mempunyai persamaan dalam kalangan mereka. Selain itu juga, menurut Mokhzan Musa (1997:31) istilah sosial itu pula dapat dilihat sebagai proses untuk membuat suatu penilaian untuk sesuatu tingkah laku manusia itu sendiri. Sesungguhnya, pelbagai pendapat atau pandangan tentang perlakuan manusia dilakukan dan kemudiannya dikategorikan dalam satu bentuk pentafsiran ataupun tanggapan. Dalam konteks ini, tanggapan ini akan membentuk kepada gambaran atau idea terhadap individu lain yang dapat digunakan sebagai panduan dalam bentuk interaksi sosial.

Selain itu, menurut Watt (1972:205) istilah novel merujuk kepada suatu laporan yang telah lengkap lagi tulen tentang pengalaman manusia dan oleh sebab itu mempunyai tanggungjawab untuk memuaskan hati pembacanya dengan memberikan perincian-perincian tentang ceritanya seperti cerita mengenai individualiti pelaku-pelakunya, waktu dan tempat berlakunya peristiwa-peristiwa, iaitu menceritakan tentang perincian yang lebih banyak untuk disampaikan melalui bahasa dan rujukan dan bukannya melalui bentuk-bentuk yang lain. Manakala, Hashim Awang (1984:45) berpendapat istilah novel itu merujuk kepada sebuah prosa cereka yang panjang, menceritakan tentang kisah hidup manusia pada suatu masa, tempat-tempat tertentu dan ia juga menyentuh tentang persoalan kehidupan yang menarik. Selain itu, novel adalah suatu karya yang panjang dan kompleks sifatnya serta mengandungi unsur-unsur dalaman seperti plot, perwatakan, latar dan sudut pandangan dalam setiap karya novel yang dihasilkan (Ali Ahmad, 1978:3) novel merupakan satu dokumentasi sosial yang isi-isinya sudah pasti mempersoalkan tentang isu-isu nilai kemanusiaan seperti perjuangan dalam kehidupan, pergolakan jiwa dan perasaan seseorang, persoalan cinta, kasih sayang, pertentangan pendapat, konflik melibatkan keadilan dan ketidakadilan yang bermain di minda dan perasaan masyarakat (Rahimah Talib, 1991:47). Justeru, apa yang dapat diperjelaskan di sini adalah fenomena sosial merupakan segala peristiwa atau kejadian yang boleh diperhatikan dan dapat diteliti dengan mata kasar serta dapat dijadikan bahan mentah dalam penghasilan sesebuah karya sastera yang sudah pasti meliputi semua perkara melibatkan kemasyarakatan iaitu dari segi aspek sosial, ekonomi, politik, kemanusiaan dan juga agama yang sentiasa bersemi dalam kehidupan masyarakat sebenar. Dalam konteks ini jelas memperlihatkan bahawa dalam suatu penghasilan karya yang melibatkan perincian sosial sudah pasti seseorang wajar menjadikan kehidupan sebenar itu sebagai kayu ukur.

Kajian ini mengandungi dua objektif: Mengenal pasti fenomena sosial dalam novel Saudagar Besar dari Kuala Lumpur menerusi aspek ekonomi, politik, sosial, budaya dan agama. Menganalisis fenomena sosial dalam novel Saudagar Besar dari Kuala Lumpur menerusi aspek ekonomi, politik, sosial, budaya dan agama. 

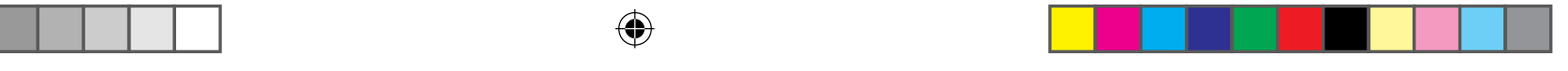

Latar belakang kajian ini akan menyentuh tentang fenomena sosial yang berlaku dalam novel Saudagar Besar dari Kuala Lumpur karya Keris Mas. Kajian ini dilakukan untuk mengkaji serta menganalisis secara menyeluruh tentang fenomena sosial yang ditemui dalam novel itu. Oleh itu, kajian ini dilakukan kerana pengkaji melihat tentang fenomena sosial dalam kalangan masyarakat pada hari ini semakin berleluasa dan menimbulkan impak negatif kepada individu, masyarakat, budaya, agama dan juga negara. Justeru, pengkaji merasa teruja untuk merungkap setiap masalah sosial yang berlaku dalam masyarakat dan mengambil contoh novel tersebut untuk dijadikan bahan kajian. Permasalahan sosial yang berlaku dalam kalangan masyarakat pada masa sekarang, ia melibatkan masalah-masalah sosial yang sering berlaku dalam kehidupan masyakat itu sendiri seperti kemiskinan, kesihatan, pergaulan bebas lelaki dengan perempuan, kecurian, rompakan, zina, jenayah siber dan sebagainya. Hal ini semakin hari semakin parah. Banyak pihak yang runsing apabila memikirkan masalah ini semakin hari semakin berleluasa sehingga boleh menggugat keharmonian serta kesejahteraan negara dan bangsa. Oleh hal demikian, permasalahan inilah menjadi medium kepada seseorang pengarang untuk menghasilkan cerita dalam sesebuah novel. Setiap pengalaman, pengetahuan dan imaginasi pengarang itu yang sebenarnya membantu seseorang pengarang itu untuk menghasilkan sesuatu karya yang bermutu dan berkualiti.

Setiap persoalan dan permasalahan yang berlaku dalam sesebuah karya yang diolah dan dikarang oleh penulis untuk masyarakat khususnya. Jika ini benar, marilah difikirkan bersama-sama untuk memberi pandangan, pendapat serta idea-idea yang bernas untuk mengekang setiap masalah sosial yang berlaku pada hari ini agar dapat diatasi bersama-sama. Bak kata pepatah yang "berat sama dipikul yang ringan sama dijinjing". Insya-Allah hasrat murni ini akan mendapat keberkatan daripada maha pencipta yang agung. Oleh itu, berdasarkan fenomena sosial yang menjadi titik tolak dalam penghasilan kajian ini, terdapat beberapa fenomena sosial yang akan di ambil kira untuk mengukuhkan lagi setiap isu yang akan dibincangkan. Antaranya ialah fenomena sosial yang dikaji meliputi aspek agama. Apabila memperkatakan tentang agama menggambarkan nilai keagamaan itu secara mutlak. Hal ini kerana keagamaan melibatkan hubungan sejati dan utuh antara umat manusia dengan maha pencipta, Allah S.W.T. Tidak dapat dipertikaikan lagi aspek agama ini sangat penting dalam kehidupan sehari-harian kerana sebagai hamba kita sewajibnya menuruti segala perintah Yang Maha Esa dalam semua perkara yang disuruh dan meninggalkan semua perkara yang dilarang. Aspek agama ini digambarkan untuk menekankan bahawa sebagai manusia perkara yang paling asas dan utama adalah jiwa serta hati mesti bertakwa dan beriman kepada Allah S.W.T sama ada di waktu mereka senang mahupun susah setelah mendapat ujian ataupun musibah dari-Nya. Sebagai manusia kita perlu sentiasa berwaspada dan mengingati serta berharap dengan segala pertolongan daripada Allah S.W.T. Justeru, nescaya manusia tidak akan lalai dan akan sentiasa memohon untuk mendapat keredaan-Nya. 

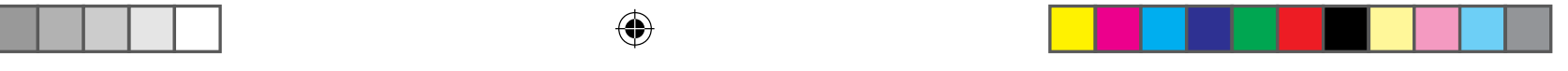

Selain itu, aspek sosial dan budaya juga dimasukkan dalam novel-novel Keris Mas. Apabila berbicara tentang aspek sosial dan budaya, ia sudah pasti melibatkan khalayak dengan kehidupannya. Hal ini kerana sosial dan budaya berkait rapat dengan hubungan manusia dan hidup mereka sehariharian. Mereka pasti melakukan pelbagai perkara yang sudah tentu dapat dilihat dengan mata kasar. Perbuatan itu seharusnya diambil iktibar untuk menjadikan manusia itu lebih peka dengan suasana sekeliling. Setiap jalinan perhubungan yang tersemai itu kadangkala sesuatu perhubungan yang baik, sihat, sempurna, serta perhubungan yang terjalin erat itu bertujuan untuk kepentingan tertentu. Dalam konteks ini, jelas menunjukkan bahawa setiap permasalahan sosial yang berlaku itu berkait rapat dengan kehidupan khalayak masyarakat yang terlibat secara langsung atau tidak langsung dan ia tidak sesekali menjadi masalah kepada manusia. Selain itu juga, terdapat juga kajian dari segi aspek ekonomi. Aspek ini merupakan aspek yang terpenting kerana bidang ekonomi merupakan dana kepada kemajuan dalam sesebuah negara untuk berkembang maju. Aspek ekonomi ini dilihat sangat berguna dan penting kepada manusia kerana ia merupakan nadi yang boleh menjamin kemajuan dalam hidup manusia secara umumnya. Aspek ekonomi yang dikaji tergambar dalam novel ini ialah melibatkan perdagangan dan pertanian. Dalam konteks ini, untuk mengusahakan sesuatu bidang perdagangan dan pertanian yang berskala besar sudah pasti memerlukan usaha serta pengorbanan yang sangat besar dan kuat dalam diri manusia. Aspek ekonomi juga dapat digambarkan dalam novel-novel karya Keris Mas. Penerapan unsur tersebut untuk menceritakan tentang kuasa ekonomi yang mampu dimiliki oleh sesebuah bangsa, kaum atau masyarakat itu secara khusus.

Seterusnya, kajian ini juga melibatkan aspek politik. Aspek politik juga merupakan aspek yang penting kepada negara. Hal ini kerana, permasalahan sosial yang melibatkan isu politik sering diketengahkan dalam novel-novel karya Keris Mas. Hakikatnya, Keris Mas jelas memaparkan sistem politik demokrasi yang diamalkan di negara ini, khususnya pemimpin dipilih melalui pilihan raya dan dipanggil wakil rakyat yang bergelar Yang Berhormat. Novel ini memaparkan kekecohan dan kekalutan penyokong parti lawan iaitu pembangkang dalam usaha mereka menentang dasar-dasar yang dibuat oleh wakil rakyat terpilih. Dalam konteks ini, aspek politik juga memainkan peranan penting dalam melancarkan lagi perjalanan cerita dalam novel-novel karya Keris Mas. Pada hakikatnya, semua penerapan idea yang disampaikan oleh pengarang mampu untuk menyampaikan mesej kepada lapisan masyarakat adalah untuk ditelaah untuk menikmati segala keindahan, difahami, dihayati dan menghargai karya sastera yang dihasilkan itu. Justeru, pengkaji boleh melihat dan merenung sejauh manakah tentang fahaman fenomena sosial ini yang digambarkan dalam novel-novel tersebut. Dengan ini, maka dapat memberi pendedahan kepada para pembaca untuk memahami peranan yang cuba dimainkan oleh seseorang watak itu untuk menusuk jiwa para pembaca. Namun begitu, setiap fenomena sosial yang dihasilkan dalam novel tersebut kebiasaannya pernah dialami dan dirasai sendiri oleh pengkarya kerana mereka pernah merasai pengalaman hidup dalam kehidupan mereka. 

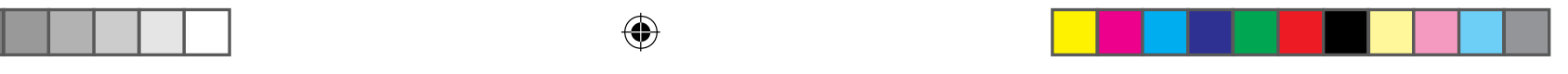

Sehubungan itu, novel Saudagar Besar dari Kuala Lumpur yang telah dihasilkan oleh Keris Mas ini akan dinilai dan diteliti secara khusus melalui aspek perspektif sosial. Hal ini kerana kajian ini akan mampu mencapai kejayaan untuk meneroka dengan lebih tepat akan fenomena sosial yang berlaku dalam novel ini. Jadi, pengkaji memilih aspek ini kerana pengkaji merasakan tentang permasalahan masyarakat yang digambarkan dalam novel karya Keris Mas ini merupakan sesuatu yang benar-benar berlaku dalam dunia hari ini kerana itu jugalah karya sastera itu sendiri mempunyai hubungan yang akrab dengan masyarakat di sekeliling mereka. Cuba kita merenung sejenak dengan minda yang celik ini, andai kata fenomena sosial yang sudah berlaku dan akan berlaku pada masa akan datang tidak dipandang serius sudah tentu akan membawa kepada kesan buruk kepada kemakmuran dan kesejahteraan rakyat jelata. Oleh itu, melalui pengkajian ini, maka permasalahan ini secara tidak langsung dapat memberi pendedahan dan kepentingan kepada seluruh masyarakat demi melihat semua fenomena sosial yang berlaku pada hari ini sangat penting untuk kita direnungi bersama.

\subsection{Teori Sosiologi}

Laurenson \& Swingewoods (1972:13) menjelaskan bahawa pengkajian sosiologi yang berfokus kepada aspek masyarakat dan kemasyarakatan merupakan satu bidang ilmu yang memberi tumpuan terhadap individu dan masyarakat secara saintifik dan objektif. Selain itu, kajian sosiologi merangkumi kajian tentang kedudukan individu dalam masyarakat, kajian mengenai institusi sosial, proses bersosialisasi serta sejarah masyarakat itu. Berkaitan dengan pertalian antara masyarakat dengan persekitaran sewaktu berkarya. Dalam hal ini, hubungan masyarakat dan persekitaran sangat rapat dan saling melengkapi untuk memahami isu-isu masyarakat dan sejarah. Untuk maksud ini, Swingewoods (1972:13), memperincikan pendekatan sosiologi dengan melihat tiga dimensi. Pertama, melihat karya sastera sebagai dokumen sosiobudaya yang mencerminkan satu zaman, kedua melihat dari segi penghasilan karya sastera terutama yang berhubungan dengan kedudukan sosial seorang penulis dan ketiga merujuk kepada penerimaan suatu masyarakat terhadap karya daripada seseorang penulis tertentu. Justeru, pendekatan sosiologi sastera dijadikan landasan pengkajian disebabkan wujudnya hubungan yang erat antara sastera dengan masyarakat. Keeratan hubungan itu bersandarkan kepada premis bahawa sesuatu karya kreatif imaginatif seperti sajak, tidak dapat dihasilkan dalam kekosongan. Sebaliknya mempunyai asas dan dorongan tertentu dengan menggunakan sumber-sumber yang terdapat di persekitaran sama ada bersifat persoalan, isu-isu ataupun fenomena tertentu yang menarik perhatian penyair. 

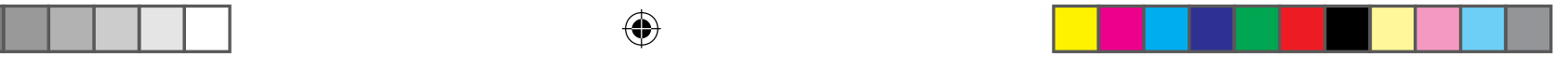

Walaupun kehidupan masyarakat dijadikan bahan untuk berkarya namun bahan tersebut telah dipilih dan disaring serta diberikan tanggapan sendiri oleh pengarang. Dalam hal ini tindak balas dengan alam dan persekitaran membantu pengarang memahami sosial milieu masyarakatnya. Dalam hubungan ini, terciptanya sesebuah karya kreatif imaginatif bukan semata-mata hasil yang dicetuskan oleh seorang pengarang sahaja. Pengarangnya berupaya memanipulasi persekitaran sebagai sumber yang membekalkan bahan untuk berkarya. Segala bentuk fenomena yang berlaku dalam lingkungan sesebuah masyarakat itu telah merangsang daya kreativiti seseorang penyair. Namun begitu, semasa berkarya mereka juga masih terikat dengan ruang dan waktu di samping mempunyai tanggungjawab terhadap masyarakat Justeru, semasa berkarya seseorang itu tidak akan melepaskan dirinya daripada tanggungjawab untuk menyampaikan mesej sama ada dalam bentuk peringatan, nasihat atau panduan kepada khalayak pembaca. Isu-isu masyarakat yang menyentuh sensitiviti mereka dijadikan idea sebelum mengolahnya dalam bentuk karya kreatif bagi mengungkapkan pemikiran melalui bahasa. Walaupun begitu, pemikiran mereka berhubung dengan persoalan masyarakat dan kemasyarakatan terungkap dalam aspek sosiobudaya, sosiopolitik dan sosioekonomi. Menurut Mana Sikana (1998:144-146) terdapat dua konsep pendekatan sosiologi yang boleh digunakan. Antaranya ialah boleh melihat karya sebagai cerminan sejarah, terutamanya tentang sejarah perkembangan ekonomi, teknologi, dan perhubungan kelas. Pendekatan sosiologi ini melihat konfrontasi dan pertikaian yang berlaku dalam masyarakat dan ia merupakan sumber inspirasi dan ilham penulis dan tugas mereka adalah untuk mencerminkan semua kejadian yang telah berlaku. Selain itu, pendekatan sosiologi ini juga boleh merakamkan aspek perwatakan dan watak-wataknya untuk menggambarkan sifat individu, personel dan berperibadi seperti yang telah ditentukan oleh masyarakat.

Seterusnya, Sapardi Djoko Damono (1978:6) menyatakan bahawa sosiologi sastera merupakan kajian tentang manusia dalam masyarakat yang merupakan cerminan secara langsung daripada setiap struktur sosial yang mempunyai hubungannya dengan kesejagatan tersebut. Selain itu, pendekatan sosiologi juga memberi kemungkinan yang sangat luas untuk menerokai nilai-nilai dalam masyarakat. Manakala, Ahmad Kamal Abdullah (1990:426) mendefinisikan pendekatan sosiologi itu sebagai satu cara untuk melihat karya yang dihasilkan itu dan mengaitkannya dengan masyarakat sama ada masyarakat tempat karya itu dihasilkan atau masyarakat yang menghasilkan itu sendiri. Selain itu juga, Mana Sikana (1998:145) pula menyatakan bahawa hubungan sastera dan masyarakat dapat dilihat seperti latar belakang pengarang, fungsi kesusasteraan masyarakat dari segi aspek sosial, ekonomi, politik, budaya dan juga pendidikan. Manakala unsur dalaman ialah karya itu sendiri. 

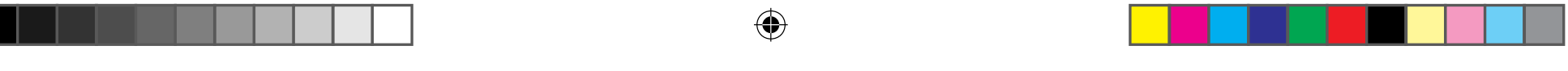

\subsection{Dapatan Kajian}

Fenomena sosial merujuk kepada permasalahan yang berkaitan dengan ekonomi, kekeluargaan, pendidikan dan kehidupan masyarakat itu sendiri. Dalam kajian ini, pengkaji akan melihat fenomena sosial yang dihadapi oleh masyarakat di dalam novel Saudagar Besar dari Kuala Lumpur karya Keris Mas ini. fenomena sosial ini terbahagi kepada beberapa aspek penting, iaitu aspek ekonomi, politik, sosial atau budaya dan keagamaan. Aspek-aspek yang akan dikaji ini mempunyai perkaitan yang sangat utuh dalam usaha pengarang untuk melahirkan sebuah karyanya yang jelas dan boleh diteliti dari sudut fenomena sosial.

\subsection{Fenomena Sosial Dari Aspek Ekonomi}

\subsubsection{Kemunculan Saudagar Melayu}

Encik Muhammad merupakan seorang ahli perniagaan Melayu yang berjaya. Sikapnya yang dedikasi diakui oleh Datuk Tan yang merupakan rakan kongsinya. Kesungguhan Encik Muhammad menceburi dalam bidang perniagaan mengubah perspektif bangsa lain terhadap bangsa Melayu yang dianggap tidak berkebolehan dalam bidang perniagaan. Karisma yang ada pada Encik Muhammad dapat digambarkan melalui petikan berikut:

" Datuk Tan tidak mendengarkan sangat keterangan itu. Tidak perlu. Dia sudah tahu mesti begitu jalannya. Tetapi diam-diam dia mengagumi kesanggupan orang Melayu ini. selalu. Selalunya orang Melayu kalau pandai mentadbir, tidak cekap merancang; kalau pandai merancang dan mentadbir, tidak tahu melangkah. Kalau tahu melangkah tidak kemas membuat penyelesaian, ada saja hujung yang longgar bila sesuatu projek diselenggarakan. Encik Muhammad ini berjalan sendiri, dari merancang, mentadbir, membuat hubungan dan seterusnya menyelesaikan. Kontrak begini bukannya mudah diperoleh dan lebih sukar untuk menyelesaikan dengan risiko-risiko yang paling kecil seperti yang telah dilakukan oleh Encik Muhammad ini."

(Keris Mas, 2006:5)

Petikan tersebut memperlihatkan kesungguhan Encik Muhammad dalam bidang perniagaan yang diceburi oleh beliau. Encik Muhammad berjaya memajukan bidang perniagaan beliau sehingga orang luar menganggap orang Melayu sudah maju dan tidak ketinggalan zaman. Dalam konteks ini, usaha yang kuat Encik Muhammad telah menjadikan beliau seorang insan yang berjaya dalam bidang perniagaan dan dipandang hormat oleh masyarakat. Menurut Laurenson \& Swingewoods (1972:13) menjelaskan bahawa pengkajian sosiologi yang berfokus kepada aspek masyarakat dan kemasyarakatan merupakan satu bidang ilmu yang memberi tumpuan terhadap individu dan masyarakat secara saintifik dan objektif. Selain itu, kajian sosiologi 

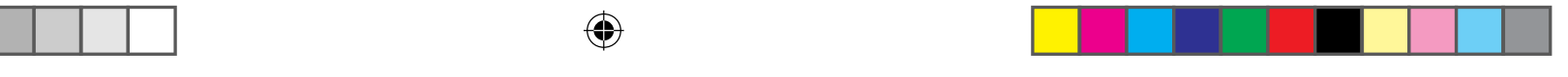

merangkumi kajian tentang kedudukan individu dalam masyarakat, kajian mengenai institusi sosial, proses bersosialisasi serta sejarah masyarakat itu. Berkaitan dengan pertalian antara masyarakat dengan persekitaran sewaktu berkarya. Dalam konteks ini, kepimpinan seseorang itu bergantung pada status kedudukan yang digalas dalam setiap organisasi kerjaya. Aspek kepimpinan ini berkait rapat kepada aspek masyarakat dan kemasyarakatan dalam sesebuah organisasi kehidupan yang dilaksanakan tersebut.

\subsubsection{Pendidikan Dalam Perniagaan}

Kepentingan pendidikan dalam bidang strategi pengurusan dagang untuk kemajuan perniagaan. Encik Muhammad mewarisi bakat dalam dunia perniagaan yang diceburi oleh datuknya. Menyedari hakikat bahawa anaknya Rahim akan mengikut jejak langkahnya, Encik Muhammad membekalkan anaknya itu dengan ilmu perniagaan di London dan kembali ke tanah air dengan ijazah Sarjana Muda Pengurusan Dagang dan bekerja dengan Syarikat Lombong Lembah Tualang. Hasrat Encik Muhammad itu digambarkan melalui petikan di bawah ini:

"Mahani tidak percaya, Jahid tentu hanya menceritakan rancangan Pak Cik Muhammad. Betapa besar hati orang tua itu sekarang. Rahim lulus dari universiti terkenal di London dengan ljazah Sarjana Muda Pengurusan Dagang tepat pada waktu Syarikat Lombong Tualang selesai ditubuhkan. Dia tidak berkali-kali menceritakan kepada pegawai-pegawai Firma Serba Dagang International tentang penglibatan datuk neneknya dalam dunia dagang dan perusahaan bijih timah. Kita akan kembali kepada perusahaan itu. Orang Melayu mesti kembali melibatkan diri mereka dalam perusahaan bijih timah. Tetapi kita mesti melengkapi diri dengan ilmu dan pengalaman tentang hal-ehwal pengurusan."

(Keris Mas, 2006:193)

Petikan di atas, jelas menggambarkan tentang kepentingan ilmu pengetahuan dalam memajukan bidang ekonomi yang dijalankan oleh manusia. Masyarakat Melayu perlu melengkapkan diri dengan ilmu pengetahuan yang luas untuk menjamin diri mereka supaya berjaya dalam setiap bidang yang diceburi, khususnya dalam kalangan orang Melayu yang minat untuk menceburkan diri dalam bidang pengurusan dagang seperti mana yang diceritakan dalam novel tersebut. Andai kata orang Melayu dapat menjaga maruah bangsa Melayu dalam bidang ekonomi yang diusahakan pasti akan menjanjikan kejayaan kepada masyarakat Melayu dan masyarakat Melayu akan dipandang tinggi oleh bangsa lain. Berdasarkan kepada pendekatan teori sosiologi yang digunakan jelas memperlihatkan tentang kepentingan pendidikan dalam memajukan perniagaan dalam sesebuah organisasi di sesebuah negeri mahupun di sesebuah negara. Hal ini menggambarkan pendidikan dan perniagaan itu berkait rapat dengan masyarakat dalam sesebuah kehidupan. Laurenson \& Swingewoods (1972:13) menjelaskan bahawa pengkajian sosiologi yang berfokus kepada aspek masyarakat dan kemasyarakatan 

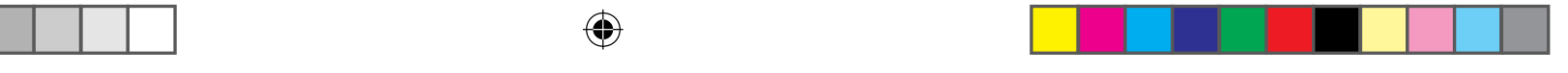

merupakan satu bidang ilmu yang memberi tumpuan terhadap individu dan masyarakat secara khususnya dalam memastikan kesuburan dan kesempurnaan dalam sesebuah negara. Dalam konteks ini, pendidikan sangat penting kepada seseorang untuk memastikan kejayaan dalam perniagaan yang diceburi. Kejayaan yang dicapai akan memastikan kedudukan perniagaan itu terus maju dan kukuh.

\subsubsection{Kemiskinan}

Aspek ekonomi yang membicarakan tentang kemiskinan orang Melayu di kawasan luar bandar. Dalam novel ini, kemiskinan jelas digambarkan oleh pengarang. Masyarakat kampung Pulai merupakan masyarakat yang hidup dalam serba kekurangan, peluang pekerjaan dan kemudahan asas tidak mencukupi. Faktor-faktor ini telah menyebabkan golongan muda berhijrah ke kota dan tidak berminat untuk tinggal di kampung halaman masing-masing. Terdapat juga penduduk yang tidak mempunyai tanah dan terpaksa menumpang tanah orang lain. Kemiskinan penduduk kampung Pulai ini digambarkan seperti berikut:

“Apa agaknya yang menyebabkan orang kita di kampung ini banyak yang susah dan senang?" Encik Muhammad bertanya. Kawan itu tidak terfikir-fikir terus sahaja menjawab, "Di sini tak ada mata pencarian selain menoreh getah, menjadi buruh JKR atau buruh Tali Air. Lain dari itu orang kampung seperti di kampung hilir sana tu pergilah ke hutan mencari buluh, mencari rotan, mencari atap bertam. Apa sahaja yang boleh jadi duit. Ada juga seorang berdua yang bekerja menangkap ikan, menjala di Sungai Tualang. Kadangkadang munasabah juga dapatnya. Harga ikan sekarang mahal. Budak-budak muda ada yang mencuba-cuba meniaga, jual asam garam, sayur-sayur kampung di market."

(Keris Mas, 2006: 41)

Berdasarkan petikan di atas, pengarang menggambarkan kehidupan miskin masyarakat di kampung Pulai secara jelas. Hal ini juga boleh mempengaruhi sistem ekonomi di kampung Pulai. Masyarakat di kampung Pulai hanya memperoleh pendapatan yang sederhana kerana penduduk di sana hanya bekerja dalam sektor biasa. Kehidupan mereka menjadi rumit disebabkan ketiadaan peluang pekerjaan yang banyak dan boleh menawarkan gaji yang berpatutan. Oleh sebab itulah ramai anak muda di kampung Pulai berhijrah ke kota besar demi mencari pekerjaan yang lebih baik untuk menyara kehidupan mereka supaya lebih baik. Memandangkan masalah kemiskinan yang dihadapi oleh masyarakat di dalam sesebuah negara itu berlegar dalam kehidupan masyarakat, maka soal kemiskinan ini boleh dikaitkan dengan pendekatan sosiologi yang berkait rapat dengan soal masyarakat dan kemasyarakatan. Laurenson \& Swingewoods (1972:13) menjelaskan bahawa pengkajian sosiologi yang berfokus kepada aspek masyarakat dan kemasyarakatan merupakan satu bidang ilmu yang memberi tumpuan terhadap individu dan masyarakat secara menyeluruh. Dalam konteks ini, soal kemiskinan mampu dilihat

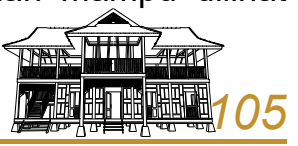


dalam skop kemasyarakatan di sesebuah negara. Justeru, pendekatan sosiologi merupakan pendekatan yang paling sesuai dikaitkan dengan soal kemiskinan kerana ia bersangkut paut dengan masyarakat.

\subsection{Fenomena Sosial Dari Aspek Politik}

\subsubsection{Perbezaan Fahaman Politik}

Fahaman politik yang berbeza membawa kepada perpecahan. Pengarang menggambarkan watak Sudin yang tidak disukai oleh sebahagian penduduk kampung Pulai kerana dia menjadi wakil kepada Yang Berhormat Muhd. Yusuf. Perbezaan parti politik telah menyebabkan penduduk kampung berpecah belah dan keadaan ini telah merunsingkan Imam Saad iaitu bapa kepada Sudin sendiri. Perpecahan fahaman politik ini dapat digambarkan melalui petikan berikut:

"Susahlah. Orang kampung berpecah-pecah. Budak-budak muda selalu bergaduh. Tak macam dulu, masa kami muda-muda, kampung ini aman. Kalau ada selisih faham, cakap Imam dan ketua kampung didengar orang." "Pecah-pecah macam mana, Pak Salim?" "Alaa. Takkan engkau tak tahu. Engkau orang politik." "Mengapa? Ada kena-mengena dengan politikkah?"

(Keris Mas, 2006:89)

Berdasarkan petikan di atas, 'apabila masyarakat mengamalkan fahaman politik yang berbezabeza ia akan membawa kepada perpecahan. Hal ini kerana, setiap orang mempunyai prinsip dan fahaman yang berlainan dalam memberi idea untuk kebajikan bersama. Andai kata terdapat sesetengah individu atau kumpulan yang tidak bersetuju dengan pendapat orang lain, akan menyebabkan berlakunya konflik dalam masyarakat. Dalam konteks ini, maka jelaslah bahawa fahaman politik yang berbeza akan membawa perpecahan dalam masyarakat jika masing-masing bertegas untuk kebaikan diri sendiri. Masalah fahaman politik yang berbeza tidak akan lari dalam bidang politik. Politik merupakan salah satu masalah yang sudah pasti menjadi fokus utama oleh masyarakat dalam sesebuah negara. Politik yang telus akan menjadikan sesebuah negara akan terus maju serta menjanjikan kejayaan untuk semua rakyat jelata. Untuk menjadikan sesebuah negara itu terus kukuh dan gemilang, kepimpinan dalam organisasi sesebuah parti politik mesti dibentuk secara kolektif dan saksama. Hal ini akan memberi kesamaan untuk semua ahli mereka. Maka soal fahaman politik yang berbeza ini boleh dikaitkan dengan pendekatan sosiologi yang berkait rapat dengan soal masyarakat dan kemasyarakatan. Laurenson \& Swingewoods (1972:13) menjelaskan bahawa pengkajian sosiologi yang berfokus kepada aspek masyarakat dan kemasyarakatan merupakan satu bidang ilmu yang memberi tumpuan terhadap individu dan masyarakat secara menyeluruh. 


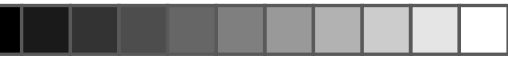

Dalam konteks ini, soal fahaman politik yang berbeza dalam sesebuah negara itu wajar dilihat dalam skop kemasyarakatan di sesebuah negara secara menyeluruh dan secara khususnya dalam sesebuah parti politik. Justeru, pendekatan sosiologi merupakan pendekatan yang paling sesuai dikaitkan dengan soal fahaman politik yang berbeza kerana ia bersandar rapat dengan masyarakat.

\subsubsection{Sejarah}

Sejarah sebagai panduan politik semasa. Malaysia merupakan sebuah negara yang berbilang bangsa. Melalui sejarah kita dapat mempelajari langkah-langkah yang telah dilakukan oleh pemimpin yang terdahulu dalam memupuk perpaduan kaum di negara ini. Datuk Tan dan Encik Muhammad menyedari kepentingan perpaduan itu untuk melaksanakan projek perkongsian mereka. Kenyataan ini dapat dibuktikan melalui petikan di bawah:

"Boleh berbahaya kalau kita tidak mengeti perjalanan sejarah. Tempat kita dalam sejarah pembangunan negeri ini ialah sebagai kongsi. Mulanya kita menjadi kongsi orang Melayu. Kemudian kita menjadi kongsi orang Inggeris. Sekarang kita mesti kembali menjadi orang Melayu. Kalau kita cuba menentang aliran ini, kita akan hancur atau kedua-duanya, Melayu dan Cina, akan hancur dan orang-orang lain akan mengambil alih."

(Keris Mas, 2006:15)

Berdasarkan petikan tersebut, kita sebagai rakyat jelata di Malaysia mesti mengerti tentang sejarah kemerdekaan negara kita. Dari dahulu lagi perpaduan sangat penting kepada semua bangsa tanpa mengira Melayu, Cina, India dan kaum-kaum yang lain. Perpaduan harus dikekalkan sampai bila-bila untuk menjamin Malaysia akan aman dan makmur sampai bila-bila. Kita mesti merujuk sejarah pada zaman dahulu dan kini sebagai panduan politik semasa untuk memupuk semangat perpaduan sesama kita dalam setiap bidang yang kita lakukan bersama. Sejarah kejayaan sesebuah negara sering kali melibatkan kegigihan dan semangat tolongmenolong yang menebal dalam diri masyarakat untuk melaksanakan sesuatu perkara. Sejarah kemajuan sesebuah negara itu dapat diukur melalui kesepakatan semua rakyat dalam sesebuah negara itu. Masalah perkauman mesti dijauhi untuk memastikan keamanan dan kesejahteraan dalam bermasyarakat. Apabila dilihat dari sudut kejayaan sesebuah perniagaan itu boleh di ukur dari aspek kesepakatan antara ahli-ahli perkongsian perniagaan yang dijalankan. Maka soal sejarah kejayaan dalam perniagaan ini boleh dikaitkan dengan pendekatan sosiologi yang berkait rapat dengan soal masyarakat dan kemasyarakatan. Laurenson \& Swingewoods (1972:13) menjelaskan bahawa pengkajian sosiologi yang berfokus kepada aspek masyarakat dan kemasyarakatan merupakan satu bidang ilmu yang memberi tumpuan terhadap individu

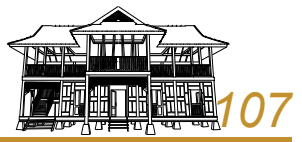


dan masyarakat secara menyeluruh. Dalam konteks ini, soal sejarah kejayaan dalam sesebuah organisasi kejayaan itu wajar dilihat dalam skop kemasyarakatan di sesebuah negara secara menyeluruh dan secara khususnya dalam sesebuah organisasi perniagaan. Justeru, pendekatan sosiologi merupakan pendekatan yang paling sesuai dikaitkan dengan sejarah perkongsian perniagaan kerana ia berharmoni dengan masyarakat.

\subsubsection{Kejujuran Wakil Rakyat}

Kejujuran seorang wakil rakyat melaksanakan amanah. Seseorang wakil rakyat mesti bersikap kerana beliau menjadi idola kepada masyarakat setiap apa yang mereka lakukan. Baik dan buruk yang ditunjukkan kepada wakil rakyat itu akan menjadi panduan kepada masyarakat untuk mencontohinya. Kalau baik perlakuannya, maka beliau akan menjadi contoh ikutan. Yang Berhormat Muhd. Yusuf merupakan seorang pemimpin yang tidak jujur dalam menjalankan tugasnya kerana mempunyai kepentingan peribadi dalam projek yang diusahakannya itu. Beliau pernah merancang untuk berkongsi dengan Tauke Chan untuk membina perumahan. Kemudiannya, beliau menyertai rancangan Encik Muhammad kerana lebih memberi keuntungan kepada beliau. Ketidakjujuran Yang Berhormat Muhd. Yusuf digambarkan melalui petikan di bawah ini:

"Dia mula merasa kecewa terhadap Yang Berhormat Encik Muhd. Yusuf, orang besar, pemimpin dan pejuang yang dipilih oleh rakyat itu. Nampaknya rakyat dalam wilayahnya tersalah pilih. Yang Berhormat Muhd. Yusuf tidak sampai sesuku pun sifat kebesaran, kepimpinan dan tanggungjawabnya kepada rakyat dan wilayah jika di banding dengan moyangnya."

(Keris Mas, 2006:35)

Berdasarkan petikan di atas, nilai kejujuran sangat penting dalam diri seseorang. Jika seseorang itu memiliki nilai kejujuran dalam diri mereka, nescaya seseorang itu akan melaksanakan semua tugas dengan penuh amanah. Seorang wakil rakyat mesti jujur untuk menjaga kebajikan masyarakat di bawah jagaannya. Jika seseorang wakil rakyat itu tidak jujur pada diri sendiri dan masyarakat di sekelilingnya, pasti akan mendatangkan kesulitan dalam menguruskan kebajikan bersama. Dalam hal ini, jelas membuktikan bahawa Yang Berhormat Muhd. Yusuf tidak jujur dalam melaksanakan amanah kepada masyarakat di kawasan jagaannya. Akhirnya, sikap beliau diketahui oleh masyarakat dan beliau telah mendapat pembalasan yang setimpal dengan pembuatan tidak bermoral itu. Nilai kejujuran sangat penting di dalam sesebuah perniagaan. Hal ini kerana kejujuran wajar diambil kira dalam setiap pelaksanaan dalam sesuatu perkara. Untuk menjadikan sesebuah perniagaan ini terus maju dan berkembang pesat, seseorang tokoh itu mesti mempunyai nilai kejujuran dalam diri mereka untuk memastikan kejayaan dalam setiap perkara yang diceburi khususnya apabila melibatkan perkongsian dalam perniagaan 
seperti petikan di atas. Hal ini akan memberi keadilan untuk semua ahli mereka. Wakil rakyat khususnya mesti mempunyai kejujuran dalam diri mereka untuk melaksanakan segala aktiviti kemasyarakatan dalam sesebuah negeri atau negara. Maka soal kejujuran wakil rakyat boleh dikaitkan dengan pendekatan sosiologi yang berkait rapat dengan soal masyarakat dan kemasyarakatan. Laurenson \& Swingewoods (1972:13) menjelaskan bahawa pengkajian sosiologi yang berfokus kepada aspek masyarakat dan kemasyarakatan merupakan satu bidang ilmu yang memberi tumpuan terhadap individu dan masyarakat secara konkrit. Dalam konteks ini, soal kejujuran wakil rakyat dalam perniagaan wajar dilihat dalam skop kemasyarakatan di sesebuah negara secara menyeluruh dan secara khususnya dalam sesebuah perkongsian perniagaan. Justeru, pendekatan sosiologi merupakan pendekatan yang paling sesuai dikaitkan dengan soal kejujuran wakil rakyat kerana ia melibatkan nilai dan maruah diri yang utuh dalam setiap bidang.

\subsection{Fenomena Sosial Dari Aspek Agama}

\subsubsection{Gerakan Dakwah Islamiah}

Gerakan dakwah Islamiah merupakan satu pendekatan dakwah yang sangat penting dalam kalangan umat Islam. Hal ini kerana pendekatan atau gerakan dakwah Islamiah ini dilakukan demi menjadikan masyarakat lebih bertamadun. Berdasarkan dalam novel ini, Lebai Maarup merupakan generasi muda yang memainkan peranan untuk mengajak masyarakat kampung kembali mengamalkan ajaran Islam dengan betul. Dia dianggap fanatik kerana memakai jubah seperti orang Arab dan bertindak menentang maksiat dan kemungkaran. Perwatakannya telah menyebabkan dia digelar oleh Yang Berhormat Muhd. Yusuf sebagai Khomeni Kampung Pulai. Kehadirannya tidak disegani oleh Encik Muhammad dan Yang Berhormat Muhd. Yusuf. Kekentalannya sebagai pendakwah dapat diamati melalui petikan berikut :

"Saya hendak beritahu semua orang, ibu bapa, adik kakak di Kampung ini bahawa saya telah dipukul orang. Saya akan terangkan kepada mereka apa sebabnya saya dipukul. Saya memang tahu mengapa saya dipukul. Saya akan katakan saya tidak akan melawan. Tapi saya akan katakan juga saya tidak akan berhenti menyampaikan kebenaran menyampaikan seruan Allah dan Rasul-Nya."

(Keris Mas, 2006: 302)

Berdasarkan petikan di atas, jelas menggambarkan tentang kekentalan Lebai Maarup dalam menyampaikan ajaran Islam yang benar kepada masyarakat di Kampung Pulai. Walaupun, Lebai Maarup mendapat tentangan daripada pihak tertentu, namun dia tetap berani untuk menjalankan dakwah Islamiah tersebut. Lebai Maarup tidak sekalipun takut dengan ugutan yang dikenakan olehnya, malah dia semakin berani untuk menyampaikan ajaran Islam itu

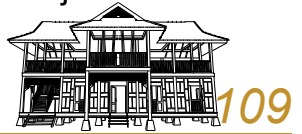


kerana dia yakin dan percaya perbuatan itu benar dan mendapat keizinan daripada Tuhan yang esa. Dalam konteks ini, membuktikan Lebai Maarup merupakan seorang insan yang berjiwa kental dan berani dalam menyampaikan ajaran Islam walaupun mendapat tentangan hebat daripada pihak tertentu. Fenomena gerakan dakwah islamiah sangat penting dijalankan di sesebuah tempat dan ia wajib disampaikan kepada semua umat manusia di muka bumi ini. perbuatan ini wajib disebarkan kepada masyarakat untuk memastikan mereka dapat mengetahui setiap ilmu agama yang diajari. Hal ini kerana gerakan dakwat islamiah ini perlu dilakukan demi mentamadunkan rakyat di sesebuah tempat, khususnya umat Islam. Oleh itu, fenomena gerakan dakwah islamiah ini juga boleh dikaitkan dengan pendekatan sosiologi yang berkait rapat dengan soal masyarakat dan kemasyarakatanLaurenson \& Swingewoods (1972:13) menjelaskan bahawa pengkajian sosiologi yang berfokus kepada aspek masyarakat dan kemasyarakatan merupakan satu bidang ilmu yang memberi tumpuan terhadap individu dan masyarakat secara tepat dan konkrit. Dalam konteks ini, gerakan dakwah islamiah sangat penting dilaksanakan khususnya untuk umat Islam bagi memastikan mereka sentiasa berpegang teguh kepada ilmu agama Allah. Justeru, pendekatan sosiologi merupakan pendekatan yang paling sesuai dikaitkan dengan fenomena gerakan dakwah islamiah dalam sesebuah kehidupan bermasyarakat tidak kita agama, bangsa dan warna kulit.

\subsubsection{Harta Pusaka}

Orang Kaya Datuk Indera Mahmud dan Encik Muhammad telah mengumpulkan ahli keluarga yang tinggal di wilayah Tualang dan tempat lain untuk mengadakan mesyuarat pembahagian sebahagian daripada harta keluarga Datuk Indera. Untuk memastikan pembahagian itu mengikut kaedah faraid turut hadir ialah kadi wilayah Tualang seperti yang dinyatakan melalui petikan berikut:

"Mesyuarat itu dipimpin oleh lawyer yang menjaga hal-ehwal harta pusaka Datuk Indera. Hadir juga bersama tuan kadi wilayah Tualang yang bertanggungjawab menolong lawyer itu membahagi harta di Kampung Pulai itu mengikut faraid."

(Keris Mas, 2006:3360)

Berdasarkan petikan di atas, Orang Kaya Datuk Indera Mahmud dan Encik Muhammad telah membahagikan harta mereka kepada mereka yang berhak menerima harta tersebut. Beliau telah melantik seorang peguam untuk menguruskan harta pusaka tersebut mengikut hukum Islam yang betul untuk memastikan anak-anak mereka memperoleh harta pusaka peninggalan selepas ketiadaan mereka nanti. Cara ini merupakan langkah yang betul demi menjaga hak-hak anak-anak mereka nanti dan langkah awal untuk mengelakkan berlaku pergaduhan antara ahli keluarga mereka yang lain.Umat Islam wajib melaksana hukum Harta pusaka mengikut hukum syarak dalam agama Islam. Hal ini kerana, Islam telah menggariskan setiap hukum hakam 
tersebut dalam al-Quran dan al-hadis. Oleh itu, pembahagian harta pusaka wajib mengikut hukum syarak untuk memastikan keadilan dan kesamaan dalam perkara tersebut. Oleh itu, pelaksanaan harta pusaka ini juga boleh dikaitkan dengan pendekatan sosiologi yang berkait rapat dengan soal masyarakat dan kemasyarakatanLaurenson \& Swingewoods (1972:13) menjelaskan bahawa pengkajian sosiologi yang berfokus kepada aspek masyarakat dan kemasyarakatan merupakan satu bidang ilmu yang memberi tumpuan terhadap individu dan masyarakat secara tepat dan konkrit. Dalam konteks ini, perlaksanaan harta pusaka mengikut syarak dalam agama Islam sangat penting dilaksanakan khususnya untuk umat Islam bagi memastikan mereka sentiasa berpegang teguh kepada ilmu agama Allah. Justeru, pendekatan sosiologi merupakan pendekatan yang paling sesuai dikaitkan dengan perlaksanaan harta pusaka dalam agama Islam.

\subsubsection{Sembahyang Berjemaah}

Amalan sembahyang berjemaah dalam novel ini digambarkan oleh pengarang tidak dititikberatkan oleh masyarakat. Bahkan sembahyang Jumaat tidak dapat dilakukan kerana tidak cukup makmum. Amalan ini dilakukan oleh golongan tua seperti Imam Saad, Bilal Endut, dan Tuk Empat Dahlan. Kedatangan Lebai Maarup menambah bilangan ahli jemaah dan berjaya menarik golongan muda ke surau seperti Kemat Jerangkung. Situasi ini digambarkan melalui petikan berikut:

"Suasana hari Jumaat itu memang amat berbeza dari Jumaat-Jumaat sebelumnya. Kecuali hari raya, surau Kampung Pulai tidak pernah dikunjungi orang seramai itu. Ada ketikanya Imam Saad terpaksa mengimamkan sembahyang Zuhur sahaja kerana tidak cukup 40 orang makmum yang hadir."

(Keris Mas, 2006:171)

Berdasarkan petikan tersebut, jelas membuktikan bahawa agama Islam menitikberatkan amalan sembahyang berjemaah dalam kalangan umat-umatnya. Pelbagai manfaat yang diperoleh oleh masyarakat yang mengerjakan solat berjemaah dan mendapat ganjaran pahala yang banyak di samping mendidik masyarakat mengasihi Allah S.W.T khususnya. Walaupun amalan ini tidak dititikberatkan dalam kalangan masyarakat dalam novel ini, namun pengarang telah menggambarkan watak Lebai Maarup berjaya menarik golongan muda ke surau seperti Kemat Jerangkung. Dalam konteks ini, penduduk kampung berjaya mengubah cara hidup mereka untuk lebih mendekatkan diri mereka kepada Tuhan yang esa. Aktiviti sembahyang berjemaah juga dituntut dalam agama Islam. Amalan ini wajib dilakukan demi memartabatkan bangsa, agama dan sesebuah negara Islam di seluruh dunia. Oleh itu, aktiviti sembahyang berjemaah wajar disuburkan dalam kalangan masyarakat setempat tidak kira di mana mereka berada. Aktiviti yang penuh dengan kesempurnaan dan kesejagatan dalam bermasyarakat ini 

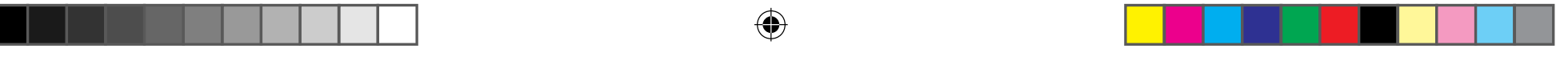

juga boleh dikaitkan dengan pendekatan sosiologi yang berkait rapat dengan soal masyarakat dan kemasyarakatan. Laurenson \& Swingewoods (1972:13) menjelaskan bahawa pengkajian sosiologi yang berfokus kepada aspek masyarakat dan kemasyarakatan merupakan satu bidang ilmu yang memberi tumpuan terhadap individu dan masyarakat secara tepat dan konkrit. Dalam konteks ini, aktiviti sembahyang berjemaah ini wajib dilakukan selalu oleh masyarakat setempat kerana Allah sentiasa menjanjikan ganjaran pahala buat mereka yang mengerjakan solat berjemaah tersebut. Justeru, pendekatan sosiologi merupakan pendekatan yang paling sesuai dikaitkan dengan aktiviti sembahyang berjemaah tersebut kerana ia melibatkan masyarakat dan kemasyarakatan.

\subsection{Fenomena Sosial Dari Aspek Budaya}

\subsubsection{Cinta}

Dalam novel ini, terdapat dua kisah percintaan iaitu percintaan tiga segi antara Sudin, Mat Akil dan Gayah. Sudin dan Mat Akil mencintai Gayah dan bermusuhan antara satu sama lain. Kemenangan akhirnya berpihak kepada Sudin. Percintaan yang kedua adalah antara Rahim dan Mahani. Percintaan ini berputik sejak dari sekolah lagi. Percintaan ini juga tidak mendapat halangan kerana Cik Puan Tipah dan Encik Muhammad memang berhasrat menjodohkan kedua-duanya sejak kecil lagi. Kisah percintaan ini dapat dilihat melalui petikan berikut:

"Dia cinta kepada Rahim. Itu sudah pasti. Kepastian itu menjadi batu pejal yang tidak mungkin pecah lagi oleh apa jua pun apabila telegramnya dijawab oleh Rahim dengan tiga perkataan saja: I love you. Telegramnya kepada Rahim mengandungi 29 perkataan yang mengajukan tiga pertanyaan: Tahukah dia ada orang datang merisik untuk melamarnya, kalau tahu apa fikirannya, dan kalau dia fikir lamaran itu perlu diterima, mengapa. I love you lebih dari menjawab semua pertanyaan itu. Apa sebenarnya yang perlu diketahuinya ialah hati Rahim. Selama ini Rahim hanya menyebut-nyebut bahawa antara dia berdua tidak ada perubahan apa-apa, sama seperti masa mereka belum berpisah kerana kepergiannya ke England dahulu. Kata-kata itu begitu sering diulang-ulang sehingga terasa menjadi ungkapan-ungkapan stereotaip yang makin lama makin terasa kaku dan kosong. Tetapi kasih sayang, cinta dan bahagia sebenarnya bukan sesuatu yang bergantung pada katakata. Cinta bukan perkara yang perlu diperkatakan tetapi dirasa, dinikmati dan diamalkan."

(Keris Mas, 2006:210) 


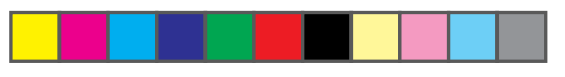

Melalui petikan berikut, setiap manusia perlukan cinta. Cinta yang suci dan ikhlas akan menjanjikan kebahagiaan kepada manusia. Cinta tidak boleh dijual beli dan dipaksa. Cinta hadir tanpa disedari dan cinta boleh membuatkan manusia gembira dan ada kalanya cinta boleh membuat manusia derita. Berdasarkan novel ini, cinta yang tersemai dalam jiwa raja watak-watak tersebut mampu menjadikan kehidupan mereka lebih sempurna kerana mereka mampu mencorek kehidupan mereka. Contohnya melalui cinta suci dan ikhlas Gayah dan Sudin. Mereka akhirnya berjaya disatukan dalam majlis perkahwinan dan cinta ini juga boleh merapatkan hubungan silaturahim antara mereka berdua. Cinta merupakan suatu budaya dalam masyarakat. Cinta berkait rapat dengan norma-norma sebuah kehidupan masyarakat. Manusia perlukan cinta kerana cinta mampu mengeratkan hubungan kemasyarakatan dalam kalangan mereka. Oleh itu, cinta boleh di terjemah dan disesuaikan dengan pendekatan sosiologi yang berkait rapat dengan soal masyarakat dan kemasyarakatan. Laurenson \& Swingewoods (1972:13) menjelaskan bahawa pengkajian sosiologi yang berfokus kepada aspek masyarakat dan kemasyarakatan merupakan satu bidang ilmu yang memberi tumpuan terhadap individu dan masyarakat. Hal ini jelas memperlihatkan bahawa budaya cinta berkait rapat dengan masyarakat dan kemasyarakatan. Dalam konteks ini, cinta memainkan peranan tertentu dalam mewujudkan budaya masyarakat yang mengalami situasi tersebut. Justeru, pendekatan sosiologi merupakan pendekatan yang paling sesuai dikaitkan dengan budaya cinta tersebut kerana ia melibatkan masyarakat dan kemasyarakatan.

\subsubsection{Pendidikan}

Dalam novel ini, Encik Muhammad menghantar Rahim menuntut di luar negara dengan harapan Rahim akan membantunya memajukan lagi syarikat perlombongan yang diterajuinya itu. Rahim dihantar belajar di London mengikuti kursus ljazah Sarjana Muda Pengurusan Dagang untuk melengkapkan diri dengan ilmu dan pengalaman tentang hal-ehwal pengurusan. Hasrat murni Encik Muhammad digambarkan melalui petikan berikut:

"Dan kemuncaknya, anaknya sendiri telah lulus dari Universiti terkenal di London dengan ijazah Sarjana Muda Pengurusan Dagang. Memang pasti ini rancangan Pak Cik Muhammad. Dia tentu percaya dengan ilmu pengetahuan pengurusan moden yang telah diperolehnya itu Rahim akan segera maju dan memperoleh pula pengalaman yang amat penting dari Datuk Tan. Tetapi apakah reaksinya terhadap penentangan Rahim yang menuduhnya menganiayai orang Kampung Pulai itu? Kalau diingat kata-kata dalam surat Rahim baru-baru ini, rasa-rasa tidak boleh dipercayai kata-kata Jahid sekarang ini.

(Keris Mas, 2006:194) 
Berdasarkan petikan di atas, Encik Muhammad sangat menitikberatkan ilmu pendidikan kepada anaknya. Encik Muhammad ingin anaknya berjaya dalam pendidikan. Encik Muhammad telah menghantar anaknya Rahim untuk melanjutkan pelajaran ke London dalam bidang Sarjana Muda Pengurusan Dagang. Hal ini kerana Encik Muhammad inginkan Rahim berjaya memperoleh ijazah dalam bidang tersebut untuk mengambil alih tugas beliau dalam bidang perniagaan dan untuk memastikan perniagaan keluarganya berjaya serta akan diteruskan sampai bila-bila. Pendidikan merupakan suatu budaya kelangsungan hidup yang wajar diteruskan oleh semua masyarakat bagi memastikan kesenangan dalam kehidupan. Masyarakat sangat menitik beratkan ilmu pendidikan kerana ia mampu membentuk masyarakat yang berilmu dan terus maju di persada kemajuan sesebuah negara. Oleh itu, pendidikan juga dapat dipadankan dengan pendekatan sosiologi yang berkait rapat dengan soal masyarakat dan kemasyarakatan. Laurenson \& Swingewoods (1972:13) menjelaskan bahawa pengkajian sosiologi yang berfokus kepada aspek masyarakat dan kemasyarakatan merupakan satu bidang ilmu yang memberi tumpuan terhadap individu dan masyarakat. Dalam konteks ini, pendidikan memainkan peranan yang sangat penting kepada masyarakat kerana pendidikan itu mampu membentuk suasana kemasyarakatan yang seimbangan dan membentuk masyarakat yang maju serta berdaya saing. Justeru, pendekatan sosiologi merupakan pendekatan yang paling sesuai dikaitkan dengan pendidikan tersebut kerana ia melibatkan masyarakat dan kemasyarakatan yang saling memerlukan untuk membentuk masyarakat yang maju.

\subsubsection{Kesihatan}

Yang Berhormat Muhd. Yusuf menyatakan kepada Encik Muhammad tentang kesibukannya hinggakan tidak ada masa untuk menjaga kesihatan diri walaupun telah dinasihati oleh Doktor. Kerisauan Yang Berhormat Mud. Yusuf digambarkan melalui petikan berikut:

"Ini bukan kesihatan dan bukan kesuburan, Encik Muhammad. Saya mulai khuatir sekarang bagaimana hendak membuang lemak yang banyak bersarang dalam diri saya. Doktor suruh saya berjalan kaki, berlari, bersukan, tetapi tak terbuat. Main golf pun saya tak terbuat. Banyak sangat kerja yang menuntut waktu saya." Yang Berhormat Muhd. Yusuf kelihatan agak sugul sedikit tetapi dia tetap tersenyum."

(Keris Mas, 2006:66) 
Manusia memerlukan tahap kesihatan yang baik dan sempurna untuk meneruskan kehidupan sehari-harian. Kesihatan yang baik akan menjadikan manusia lebih sempurna melakukan sebarang aktiviti di muka bumi Allah ini. Encik Muhammad alpa untuk menjaga kesihatannya kerana terlalu sibuk menguruskan perniagaannya. Demi memajukan perniagaan yang dijalankan, Encik Muhammad jarang melakukan pemeriksaan kesihatan di klinik ataupun hospital. Setelah beliau mendapati kesihatan beliau terganggu, beliau telah berjumpa dengan Doktor untuk melakukan pemeriksaan kesihatan. Doktor telah menasihatkan beliau untuk menjaga kesihatan demi memastikan kesihatan yang berpanjangan. Aspek kesihatan merupakan suatu perkara yang peting kepada manusia. Kesihatan yang baik dan sempurna akan menjadikan masyarakat hidup dalam situasi yang baik. Kesihatan juga sudah sinonim dengan sesebuah kehidupan masyarakat di muka bumi ini. kesihatan juga merujuk kepada individu masyarakat yang menjaga kesihatan diri demi kelangsungan hidup mereka. Masyarakat sangat menitik beratkan kesihatan kerana apabila seseorang individu masyarakat itu sihat dan sejahtera, maka mereka dapat melakukan sebarang aktiviti seharian dengan sempurna. Oleh itu, kesihatan juga dapat dihubungkan dengan pendekatan sosiologi yang berkait rapat dengan soal masyarakat dan kemasyarakatan. Laurenson \& Swingewoods (1972:13) menjelaskan bahawa pengkajian sosiologi yang berfokus kepada aspek masyarakat dan kemasyarakatan merupakan satu bidang ilmu yang memberi tumpuan terhadap individu dan masyarakat. Dalam konteks ini, kesihatan yang sempurna dan baik akan melahirkan masyarakat yang sihat dan dapat melakukan segala aktiviti kemasyarakatan dengan kompleks. Justeru, pendekatan sosiologi merupakan pendekatan yang paling sesuai dikaitkan dengan kesihatan tersebut kerana ia melibatkan masyarakat dan kemasyarakatan yang saling memerlukan untuk membentuk masyarakat yang harmoni.

\subsection{Penutup}

Pemaparan fenomena sosial dalam novel ini menggambarkan wujudnya hubungan sastera dengan kelompok masyarakatnya. Ini membuktikan gagasan teori sosiologi Laurenson \& Swingewoods (1972:13) yang menyatakan bahawa kewujudan fenomena-fenomena sosial dalam karya berkait rapat dengan bayangan realiti kehidupan masyarakat di luar adalah sangat bersesuaian. Oleh itu, berdasarkan objektif kajian ini, pengkaji menemui terdapatnya fenomena-fenomena sosial yang terpapar dalam novel Saudagar Besar Dari Kuala Lumpur. Kesemua fenomena sosial yang dikenal pasti telah dianalisis dengan melihat daripada beberapa aspek iaitu ekonomi, politik, budaya dan agama. 


\section{Rujukan}

Ali Ahmad. (1978). Asas Menganalisa Cereka. Kuala Lumpur: Dewan Bahasa dan Pustaka.

Hashim Awang. (1983). Seuntai Mutiara Klasik. Petaling Jaya: Penerbit Fajar Bakti Sdn.Bhd.

Hashim Awang. (1984). Kesusasteraan Melayu dalam Kritikan dan Sejarah. Kuala Lumpur. Dewan Bahasa dan Pustaka.

Kamaruzzaman A.Kadir. (1987). Nasionalisme dalam Puisi Melayu Moden 1933-1957. Kuala Lumpur: Dewan Bahasa dan Pustaka.

Laurenson, Diana and Swingewood, Alan. (1972). The Sociology of Literature. Granada Publishing Limited, London.

M.K Danziger \& W.S Johnson. (1991). Pengenalan Kritikan Sastera. Terj. Hamdan Yahya, Johan Jaafar dan Shamsuddin Jaafar. Kuala Lumpur: Dewan Bahasa dan Pustaka.

Mana Sikana. (1986). Teori dan dan Pendekatan Kritikan Sastera Moden. Shah Alam: Penerbit Fajar Bakti Sdn. Bhd.

Mohd Taib Othman. (1988). Bunga Rampai Kebudayaan Melayu. Kuala Lumpur: Dewan Bahasa dan Pustaka.

Keris Mas. (2003). Saudagar Besar Dari Kuala Lumpur. Kuala Lumpur: Dewan Bahasa dan Pustaka.

Sapardi Djoko Damono. (1978). Sosiologi Sastera Sebuah Pengantar Ringkas. Jakarta: Jabatan Pendidikan dan Kebudayaan.

Sidi Gazalba. (1967). Pengantar Kebudayaan Sebagai IImu-Buku 11, Djakarta: Pustaka Aman,:1-2.

Umar Yunus. (1989). Stilistik Satu Pengantar. Kuala Lumpur: Dewan Bahasa dan Pustaka. 